\title{
HAVE-perfects in Post-classical and Early Byzantine Greek*
}

\author{
Klaas Bentein \\ Ghent University \\ Klaas.Bentein@UGent.Be \\ Sobre los perfectos con HABER en griego Post-clásico
y Bizantino temprano
}

In this article, I analyze the use and development of periphrastic perfect constructions with the Ancient Greek verb «have» ("̌ $\chi \omega)$ in Post-classical and Early Byzantine Greek. To be more specific, I discuss the following four constructions: (a) ع $\chi \omega$ with active/middle aorist participle (anterior); (b) $\varepsilon \chi \omega$ with passive perfect participle (resultative); (c) $\varepsilon \chi \omega$ with passive aorist or present participle (resultative) and (d) $\varepsilon \chi \omega$ with active/middle aorist or present participle and a temporal adjunct (anterior). My analysis is based on a registerbalanced corpus of texts, whereby I distinguish between works of a «low», «middle» and «high» register.

Key words: Ancient Greek; perfect; periphrasis; diachrony; register.
En este artículo analizo el uso y desarrollo de las construcciones perifrásticas de perfecto con el verbo $\varepsilon \chi \omega$ en el griego post-clásico y el bizantino temprano. Concretamente, examino las cuatro construcciones siguientes: (a) है $\chi \omega$ con el participio aoristo activo/medio (anterior); (b) है $\chi \omega$ con el participio de perfecto pasivo (resultativo); (c) $\varepsilon$ $\chi \omega$ con el participio aoristo o presente pasivo (resultativo) y (d) $\varepsilon \varkappa(\omega$ con el participio aoristo o presente activo/medio y complemento temporal (anterior). Mi análisis se basa en un corpus lingüístico variado, en el que distingo las obras de registros «bajo», «medio»y «alto».

Palabras clave: griego antiguo; perfecto; perífrasis; diacronía; registro.

* Parts of this article were presented at the «Fifth International Conference of the German Cognitive Linguistics Association» (Freiburg, October 10-12, 2012). I would like to thank an anonymous referee of Emerita for his/her comments on a previous version of the article, as well as Wolfgang de Melo, Kristoffel Demoen, Trevor Evans, Mark Janse and Albert Rijksbaron for helpful suggestions (any mistakes or inaccuracies remain entirely my own responsibility). My work was funded by the Special Research Fund of Ghent University (grant no. 01D23409). 


\section{INTRODUCTION}

As Haspelmath 1992 among others has shown, during the history of the Greek language the synthetic perfect underwent two major semantic shifts, whereby it came to denote an increasingly more salient (past) event ${ }^{1}$ : from resultative (stative) to anterior in the Classical period, and from anterior to perfective past in the Post-classical period (both shifts being common from a cross-linguistic point of view, see Bybee, Perkins \& Pagliuca 1994)2. This increase in (past-) event-orientedness led to the functional merger of the synthetic perfect and aorist, as illustrated in (1) (where the two tenses are co-ordinated in narration), ultimately resulting in the loss of the former (for reasons which are still unclear).

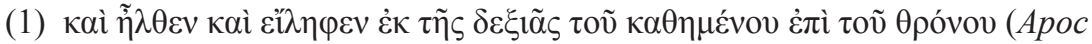
$5.7)^{3}$

the Lamb went over and took the scroll from the right hand of the one who sat on the throne $(\mathrm{CEV})$

In the context of this restructuring of the verbal system, many scholars have drawn attention to the importance of periphrastic constructions, mainly

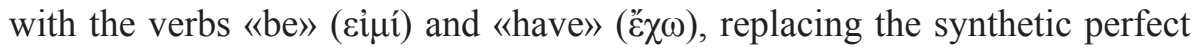

1 The functions of the perfect (as a universal semantic category) can be placed onto a continuum which ranges from subject-orientedness (or state-orientedness) to event-orientedness (as reflected in discourse-use), with a major distinction between a resultative perfect (e.g. $\gamma \varepsilon \dot{\gamma} \rho \alpha \pi \tau \alpha \iota$ «it stands written», $\tau \dot{\varepsilon} \theta v \eta \kappa \alpha$ «I am dead») and an anterior perfect (e.g. $\gamma \varepsilon \dot{\gamma} \gamma \rho \alpha \varphi \alpha$

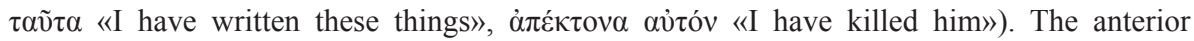
perfect can be further divided into four subfunctions, called «perfect of current relevance», «experiential perfect», «perfect of persistence» and «perfect of recent past» (Bentein 2012, pp. 175-182).

2 There is no consensus as to when these shifts should be dated, which can be (partly) attributed to the fact that we are dealing with a continuous process (especially in the case of the second semantic shift), whereby examples with the «old» aspectual function remain in use (what is called «persistence»). The first shift is often dated to the Classical period (V-IV BC) (but see Ruijgh 2004, p. 32 for an earlier dating), while the second shift to the Early Post-classical period (III-I BC) (but see Porter 1989, p. 273 for a much later dating).

${ }^{3}$ The Greek text of the examples is based on the Thesaurus Linguae Graecae (http:// stephanus.tlg.uci.edu) and for the papyri on the Duke Databank of Documentary Papyri (http:// www.papyri.info). For the abbreviations of the Post-classical and Early Byzantine texts, I refer to Lampe 1976. 
(see e.g. Gerö \& von Stechow 2003, p. 283; Dickey 2009, p. 155; Horrocks 2010, p. 178), together with the synthetic aorist. Up until now, however, there have been surprisingly few systematic investigations of a representative sample of Post-classical and Byzantine texts (the standard works remaining Aerts 1965 and Moser 1988; but see recently Giannaris 2011a, 2011b, focusing on the construction with eijuí). In this article, I present the findings of a corpusbased research on periphrastic constructions in Ancient Greek, concentrating on so-called HAVE-perfects, i.e. constructions with है $\chi \omega$.

The approach adopted here could be called «socio-historical» (see e.g. Romaine 1982; Milroy 1992) in the sense that particular importance is attached to two interrelated issues which have not received due attention in the literature. Firstly, I believe we must try to distinguish more sharply than is usually done between «innovation» (i.e. the creation of a novel construction) and «propagation» (i.e. the process whereby the novel construction becomes conventional, i.e. an integrated part of the grammar) (what Croft 2006, pp. 9899 calls «first order variation» versus «second order variation»), which can be situated at the level of the individual and the community respectively. In general, attention has almost exclusively gone to the propagation of constructions (especially within the framework of grammaticalization theory), but it should be stressed that (a) every conventionalized construction has started out as an innovation; (b) it is worth investigating the factors that determine why one construction becomes successful and another does not (what Mufwene 2001 calls language-internal and language-external «ecological» factors). Secondly, many scholars have noted the difficulties accompanying the linguistic study of Post-classical and Early Byzantine Greek (see e.g. Browning 1969, p. 13: «any formal utterance, and in particular any written sample of language, differed considerably from "normal" speech»). In an attempt to reconstruct or approximate the spoken language, attention has almost exclusively gone to «authentic» texts such as the papyri and other low-register documents (see e.g. Mirambel 1966, pp. 169-170; Browning 1969, p. 14). While I do not want to deny the importance of these documents for our linguistic analysis, I would like to advocate a different approach, whereby it is recognized that Ancient Greek can only be approached as a text- or corpus-language (Fleischman 2000), and that we will never be able to investigate the spoken language directly. As a result, I believe our primary aim should be to describe and analyze (and if possible account for) the variation found in different types of written text. A similar approach has recently been advocated by Manolessou: 
Since the only thing we possess is written documents, we can never hope to investigate spoken language, or the language of the illiterate majority of the population. What we can describe eventually is the (historical and geographical) provenance and register level of all the extant variants, and the factors governing their distribution in written language (Manolessou 2008, p. 74).

What is needed, therefore, is a corpus which gives a representative overview of the different linguistic levels or registers found in written language, or what O'Donnell 2000 has called a «register-balanced corpus» (on register from a general linguistic point of view, see e.g. Biber \& Conrad 2009) ${ }^{4}$. For the purposes of this article, I will distinguish between three registers, which I call «low», «middle», and «high» (following the recent studies of Høgel 2002 and Markopoulos 2009; for a different proposal, see e.g. Porter 1989, pp. 152-153). It should be stressed, however, that these three registers constitute points on a continuum (cf. Biber \& Conrad 2009, p. 33: «while register differences can be regarded as a continuum of variation, genre differences are more concrete»): for example, two authors (or even one and the same) can both write in a linguistically high level, but differ in degree of Atticism 5 .

The corpus I have compiled consists of texts belonging to three groups, that is: (1) non-literary (documentary) papyri, (2) biographical/hagiographical texts, and (3) historiographical texts, covering the period from the third century $\mathrm{BC}$ to the eighth century AD (for an overview of the literary sources, see the appendix $)^{6}$. Generalizing, the non-literary papyri can be located to-

${ }^{4}$ The interrelationship between register and diachrony has received almost no attention whatsoever. The recent study of Markopoulos 2009, however, has convincingly shown the relevance and importance of such a register-based approach. Markopoulos concludes his book by observing that «the rise in the frequency of use and the establishment of a construction in a specific register almost without exception follows the demise of another in the same register, so that a situation whereby two or more AVCs [= auxiliary verb ("periphrastic") constructions, $\mathrm{KB}$ ] are equally frequent in a genre or in all contexts in a period never obtains» (Markopoulos 2009 , p. 226), and posits what he calls a «fifth, sociolinguistic, parameter of grammaticalization», which predicts that «the further grammaticalized an AVC becomes, the higher up it rises in terms of sociolinguistic (register) acceptability» (Markopoulos 2009, p. 232).

${ }^{5}$ Note that even within one text we can have register-variation. As O'Donnell 2000, p. 277 notes: «on the whole, the New Testament is closest to the non-literary variety, though parts might be considered vulgar (e.g. Revelation), while others could be seen as close to literary (e.g. Hebrews)».

${ }^{6}$ The only text which is less easily classified under one of these three groups is the Septuagint, which I have also included in the investigation (being one of the major linguistic sources for the Early Post-classical period). 
wards the left side of the register-continuum, the biographical/hagiographical texts towards the middle, and the historiographical ones towards the right side, as shown in figure 1:

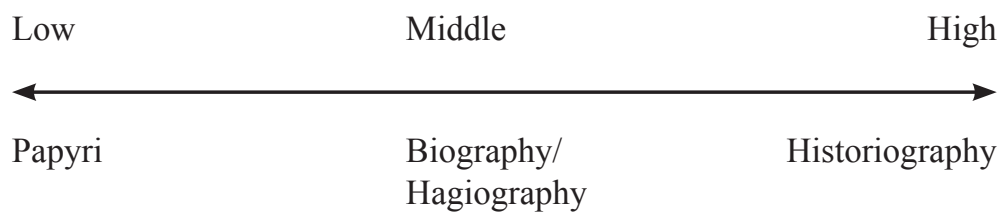

Figure 1. The register-continuum (Post-classical and Early Byzantine Greek).

In what follows, I discuss each of these groups in greater detail, with particular attention to three situational characteristics, namely (a) author, (b) addressee, and (c) content/communicative purpose. As we will see, with each of the three groups it is necessary to bring some nuance to their proposed position on the register-continuum. Figure 1 only provides a necessary starting point, and can be considered a crude generalization.

1. Non-literary (documentary) papyri. - Contrary to biography/hagiography and historiography, the papyri are (mainly) non-narrative groups, which (to a large extent) explains why we find them at the left of the continuum. Conventionally, the documentary papyri are divided into two main groups (and then further sub-divided) on the basis of addressee: «private» (e.g. private communications, records of transactions, documents of piety) versus «public» (e.g. petitions to officials, tax receipts, pronouncements of the government/administration). While in general most attention has gone to the language of the private documents, which are taken to be written by ordinary people in an unpretentious language, we must be careful not to overgeneralize. For one thing, private documents with an «official» character were often written in a more formal register ${ }^{7}$. Moreover, even in the case of the private letters, the educational level of the author could greatly vary (as Salonius 1927, p. 3 writes: «sie sind von Hunderten von Personen verfasst, von dem

${ }^{7}$ In this context, Mandilaras 1972, p. 10, discussing the language of the papyri, makes a broad distinction between two main types of language, «the official language» (official and business documents) and the «popular language» (private letters), observing with regard to the former that «this form of the language is in general artificial, characterized by repetitions, and built on stereotyped expressions which are always found in the bureaucratic system». 
hochgebildeten griechischen Weltmann an bis zu dem rohen römischen Veteranen und dem ägyptischen Fronarbeiter oder dem Schuljungen»).

2. Historiographical texts.- At the other end of the continuum, we find the historiographical texts. Indeed, the differences with regard to the three above mentioned situational characteristics could not be greater: the authors of these texts were well educated, writing about the glorious political/military deeds of the past, directing their work at an educated «international» public. Again, however, some nuance is necessary. A distinction which is commonly made is that between (more traditional) historiographical works, which in the line of Herodotus and Thucydides try to give an impartial treatment of shorter periods of time, and so-called «chronicles», which start with the creation of the world and continue to the time of the author, often with the purpose of showing the hand of God in historical events. Works of the second type (in our case, the chronicles of John Malalas and Theophanes Confessor, next to the so-called Paschal Chronicle) were generally written in a less elevated language than the (often) classicizing histories. Even with the first type of texts, however, there were some authors who wrote in a lower register (Polybius being a well-known example, see e.g. Horrocks 2010, p. 96).

3. Biographical/Hagiographical works. - The third group, which I have situated towards the middle of the register-continuum, is the most disparate with regard to the above-mentioned situational characteristics. In comparison with historiography, biographical/hagiographical texts did not aim at recounting the glorious events of the past, but rather focused on a single personality (Cox 1983, p. 12) ${ }^{8}$. Since most of these texts are written in a much lower register than the historiographical ones (see Høgel 2002, p. 25 «an idea of simplicity permeated hagiography»), it would seem that they were directed at a much broader audience (readers and listeners!), including people from the general populace (Høgel 2002, p. 30). Their authors could belong to the lower strata of the society, but the picture is diverse (in any case, we must take into account that these authors were literate, which was a privilege in se): they were written by followers of the saints, monks, deacons, and occasionally even by people with a very high social position, such as the patriarch Athanasius (Høgel 2002, p. 29).

\footnotetext{
${ }^{8}$ See already Plu., Pomp. 8.6.
} 
Several remarks are in order. Firstly, the corpus also contains a selection of Plutarch's pagan biographies, which were written in the high register (since Plutarch adopted the «chronological» rather than the «topical» mode for his biographies - see Cox 1983, p. 56- his work is much closer to historiography anyway). Secondly, as can be seen in the appendix, biography/ hagiography does not constitute a uniform genre: the corpus contains acts, apocalypses, gospels, encomia, homilies, miracles, laudations, lives, and passions. Of these, especially the encomia, homilies and laudations (i.e. subgenres concerned with praise) are more rhetorically elaborated (see Høgel 2002, p. 22) and hence positioned more towards the right of the register-continuum. Thirdly, the genre itself was subject to diachronic changes: when in the fourth century Christianity received imperial support, the Cappadocian fathers (who were highly educated) did not write «simple language», but adopted the «style, form and vocabulary of their own earlier training» (Cameron 1991, p. 111), even in hagiography ${ }^{9}$. As a result, biographical/hagiographical texts «ranged over the entire literary spectrum and appealed to readers of all educational levels» (Cameron 1991, p. 147).

For the diachronic analysis that is to follow, I have divided the Postclassical and Byzantine periods (i.e. the period from the $3^{\mathrm{d}} \mathrm{c}$. BC to the $8^{\text {th }}$ c. AD) into four sub-periods (following up on a suggestion by Lee 2007, p. 113), called «Early Post-classical Greek» $(E P G)\left(3^{\text {d }} \mathrm{c} . \mathrm{BC}-1^{\text {st }} \mathrm{c} . \mathrm{BC}\right)$, «Middle Post-classical Greek» (MPG) $\left(1^{\text {st }} \mathrm{c}\right.$. AD $\left.-3^{\mathrm{d}} \mathrm{c} . \mathrm{AD}\right)$, «Late Postclassical Greek» (LPG) $\left(4^{\text {th }} \mathrm{c} . \mathrm{AD}-6^{\text {th }} \mathrm{c}\right.$. AD) and «Early Byzantine Greek» $(E B G)\left(7^{\text {th }} \mathrm{c} . A D-8^{\text {th }} \mathrm{c} . \mathrm{AD}\right)$. Data from these texts have been collected on the basis of two online (lemmatized) databases, the Thesaurus Linguae Graecae (TLG) ${ }^{10}$ (biography/hagiography and historiography) and the Duke Databank of Documentary Papyri (DDBDP, version 2010) ${ }^{11}$ (papyri). While these are invaluable resources for large-scale diachronic research, it must not be forgotten that they have their limitations. The main disadvantage of the TLG is that it does not display the critical apparatus. Recent research, however, has emphasized the importance of studying these variants for dia-

${ }^{9}$ As Høgel (2002, p. 27) notes, however, high-register hagiographical texts are mostly confined to the fourth and seventh/eighth centuries (with authors such as Sophronius, Gregory the Presbyter, Ignatius the Deacon, and Stephan the Deacon).

${ }^{10}$ At http://stephanus.tlg.uci.edu (University of California).

${ }^{11}$ At http://www.papyri.info (Duke University). 
chronic linguistic research (see e.g. Fleischman 2000; Markopoulos 2009). A limitation of the DDBDP (which does display the critical apparatus) is that it does not mention the number of words for each text (which, undoubtedly, can be attributed to the nature of these documents), as a result of which it will not be possible to provide normed rates of occurrence (i.e. number of instances per 10000 words, henceforth abbreviated as NRO) when discussing the papyri ${ }^{12}$.

\section{HAVE-perfects in Post-classical and Early Byzantine Greek}

\section{1. "E $\chi \omega$ with active/middle aorist participle (anterior)}

With the exception of EBG, examples of $\varepsilon^{\prime} \chi \omega$ with an active or middle aorist $^{13}$ participle (with an anterior function) can be encountered in all of the periods under analysis. In illustration, consider (2), from Cassius Dio' Roman Histories:

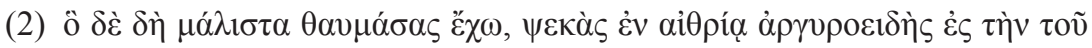

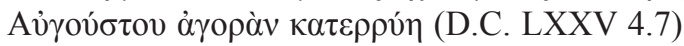

but what I have marveled at most was this: a fine rain resembling silver descended from a clear sky up the Forum of Augustus (tr. Cary, slightly modified)

That such examples still occur in Post-classical Greek may come as a surprise: as Aerts (1965, pp. 128-160) has shown, the construction emerged as an anterior perfect in the fifth and fourth centuries BC, in close connection with the evolution of the synthetic perfect and the periphrastic perfect with

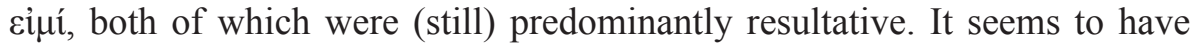
been especially favored in poetry (perhaps for metrical reasons, but this needs further research), as in (3), from Sophocles' Antigone. However, with the rise of alternative expressions for the anterior function, the construction gradu-

12 To get a rough image of the number of papyri per period studied, we can rely on the study of Habermann 1998, according to whom the Early Post-classical papyri represent $20 \%$ of the total number of papyri, the Middle Post-classical ones almost 50\%, the Late Post-classical ones $23 \%$ and the Early Byzantine ones only 7\%. For further discussion, I refer to Dickey 2003.

${ }^{13}$ Much less frequently, we find the active/middle perfect participle in this type of con-

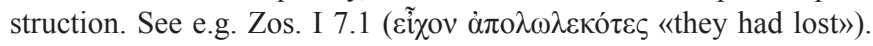


ally disappeared (according to Aerts 1965, p.160, this development can be situated in the first half of the fourth century BC).

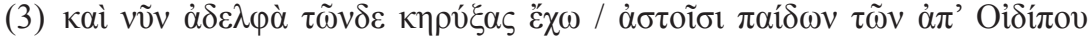
$\pi \varepsilon \dot{\rho}$ (S., Ant. 192-193)

akin to these is the edict which I have now published to the citizenry concerning the sons of Oedipus (tr. Jebb)

When looking at the distribution of the construction in the literary texts from my corpus, shown in Table 1, we can make two observations:

Table 1. Distribution of है $\chi \omega$ with active/middle aorist participle

\begin{tabular}{|l|l|l|c|c|}
\hline \multicolumn{1}{|c|}{ Period } & \multicolumn{1}{|c|}{ Author } & \multicolumn{1}{c|}{ Text } & Total & NRO \\
\hline I BC & Dionysius of Halicarnassus & Roman Antiquities & 10 & 0,3 \\
\hline I - II AD & Plutarch $^{15}$ & Parallel lives & 3 & 0,2 \\
\hline II - III AD & Cassius Dio $^{\text {Roman Histories }}$ & 10 & 0,3 \\
\hline IV - V AD & Eunapius & Historical Fragments & 2 & 1,2 \\
\hline V AD & Sozomenus & Ecclesiastical History & 1 & 0,1 \\
\hline
\end{tabular}

Firstly, this table indicates that the use of E $\chi \omega$ with aorist participle was pragmatically restricted: it can only be found in historiographical texts of the high register ${ }^{15}$. Similarly to Aerts (1965, p. 160), I believe the driving force behind employment of the construction must have been the wish for imitation of the examples from Classical Greek (for Classical examples with the verb

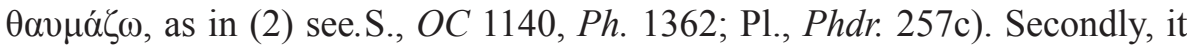
may be clear that even in these high-register works, the construction never occurs with high frequency (NRO being the highest in Eunapius, with 1,2

${ }^{14}$ See the appendix for the specific selection of live.

${ }_{15}$ Also observe that there are no occurrences of the construction in Early Byzantine high-register texts. This constitutes an interesting parallel with the distribution of the constructions of Eijui with perfect and aorist participle, which are also virtually absent in these works (with an NRO of 0,8 and 0,7 respectively). It could be that the high-register texts of the EBG period should be situated more to the right on the register scale, and that in these texts the synthetic tenses (including the synthetic perfect) are more often used, but this needs further research. 
instances per 10000 words). Clearly, we are dealing here with what Croft calls «innovation» or «first order variation» $(\mathrm{cf} . \mathrm{I})^{16}$.

It is worth noting that - contrary to what one would expect - I have come across three examples of $\varepsilon^{\prime} \chi \omega$ with active/middle aorist (perfect) participle in the papyri (from the Middle and Late Post-classical periods) ${ }^{17}$. It is not entirely clear to me what may have motivated the use of the construction in these documents: we could be dealing with a «true» innovation (i.e. one which is not motivated by the wish for imitation of the Classical examples) ${ }^{18}$, or it may be that the higher register of these texts (especially POxy. XII 1408 and POxy. XIX 2228, which are official documents) has stimulated the use of this type of construction.

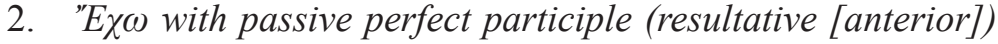

"E $\chi \omega$ with passive ${ }^{19}$ perfect participle is perhaps the most well-known HAVEperfect construction, because of its equivalents in Latin and the Romance languages. Two typical examples would be (4) and (5):

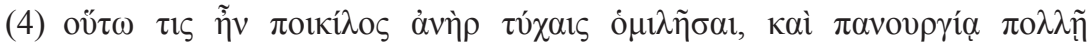

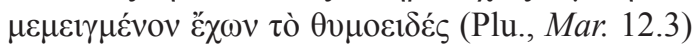

so versatile was he in adapting himself to the turns of fortune, and so great craft did he combine with his courage (lit. having his courage combined with great craft) (tr. Perrin)

16 Perhaps the term «innovation» is less appropriate here, since the construction can already be found in Classical Greek. My point is that the construction never really became successful in a broader range of texts (not even in the high register), and was only occasionally used by a restricted number of authors.

${ }^{17}$ See POxy. XII 1408, 1. 12 (III AD) ( $\chi^{\prime} \chi \omega \pi \rho \sigma \tau \alpha \dot{\xi} \xi \alpha \varsigma$ «I have ordered»), POxy. XIX

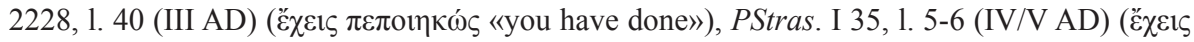
$\pi \dot{\varepsilon} \mu \psi \alpha \varsigma$ «you have sent»).

${ }^{18}$ It could be that in PStras. I 35, 1. 5-6 we are dealing with an innovative extension of the construction discussed in II.4, where $\varepsilon^{\prime} \chi \omega$ is combined with a present or aorist participle

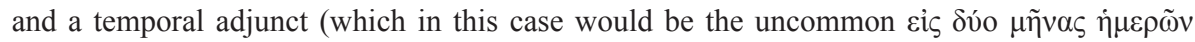

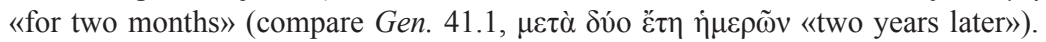

${ }_{19}$ Much less frequently, we find an active perfect participle in this type of construction.

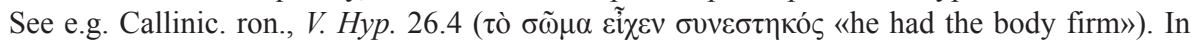
the remainder of this article, I will continue to refer to the construction as «है $\chi \omega$ with passive perfect participle». 


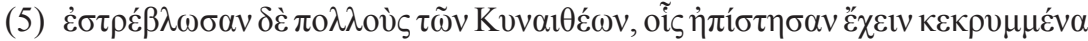

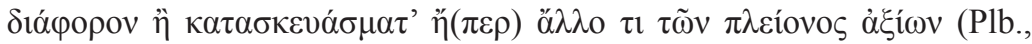
Hist. IV 18.8)

they tortured many of the Cynaetheans whom they suspected of having concealed money, plate, or other valuables (tr. Schuckburgh, slightly modified)

In both cases, we are dealing with a resultative perfect construction, indi-

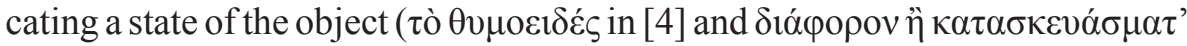

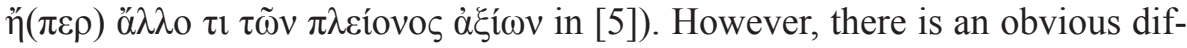
ference between these two examples in the sense that only in the second case is an alternative reading possible, whereby the periphrastic perfect is interpreted as an anterior perfect, denoting the current relevance of a past event (i.e. hiding valuable things). It must be stressed, however, that as long as there is concord between the accusative object and the perfect participle, this alternative interpretation can only come about through pragmatic inference (on which see e.g. Traugott \& Dasher 2002), i.e. in contexts where the subject of $\varepsilon^{\prime} \chi \omega$ can also be taken as the agent of the event denoted by the participle.

There is no consensus as to the origins and diachronic evolution of this type of construction. Horrocks (2010, p. 132) writes that $\chi^{\prime} \chi \omega$ with passive perfect participle («in an active transitive sense», i.e. as an anterior pragmatic inference) «is a very strong candidate for classification as a "Latinism" in the koiné, though not one which made much impact at the time, being alien to the general structure of a still prestigious world language». He furthermore adds that:

this is a wholly unclassical construction, which begins to appear in the more polished «literary» registers of the Koine in the Roman period (e.g. in the writings of the historian Diodorus Siculus or the biographer and essayist Plutarch). It is not used by the Atticists, and it does not appear in low-level literary or subliterary texts. Furthermore, with the advent of a more stringent Atticist approach in the $2^{\text {nd }}$ century $\mathrm{AD}$, it quickly disappeared even from stylistically middle-brow compositions, and eventually reappears in popular varieties of Greek only after the «Latin» conquest of much of the Byzantine empire after the capture of Constantinople by the fourth crusade in 1204 (Horrocks 2010, pp. 131-132).

Horrock's view faces some serious difficulties. In general, I do not see much reason to limit the discussion to $\ddot{\chi} \chi \omega$ with passive perfect participle «in an active transitive sense»: as I have shown, the anterior function of the construction (coming about through pragmatic inference) is clearly related to the 
resultative one (which is predominant). Furthermore, the proposed diffusion and chronology are incorrect. Our earlier example (4) (from Polybius) indicates that the construction can already be found at an earlier stage, in Early Post-classical Greek ${ }^{20}$. Horrocks considers the construction «wholly unclassical» and "alien to the general structure of a still prestigious world language» (cf. also Jannaris 1897, p. 498), but this may be questionable: instances of the construction can already be found in Archaic and Classical Greek, as shown in (6) (cf. also Thielmann 1891, pp. 305-306):

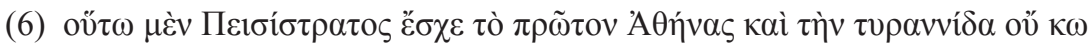

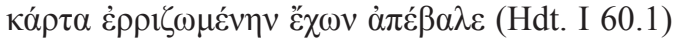

in this way Pisistratus first got Athens and, as he had a sovereignty that was not yet firmly rooted, lost it (lit. having the sovereignty not yet firmly rooted) (tr. Godley)

It is true that in (Early) Latin a structurally similar construction (with the verb habeo «I have») appeared, as illustrated in (7) (I borrow this example from Haverling 2009, p. 358). However, the early presence of examples of Ě $\chi \omega$ with passive perfect participle in EPG (and already in Archaic/Classical Greek) precludes any direct influence from Latin on Greek. ${ }^{21}$

(7) virtute ... et maiorum et tua / multa bona bene parta habemus (Plaut., Trin. 346-347)

thanks to our forebears and yourself, we are well supplied with wellearned means (tr. Haverling)

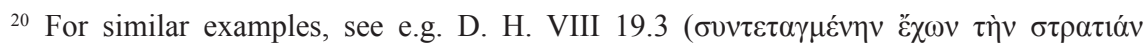

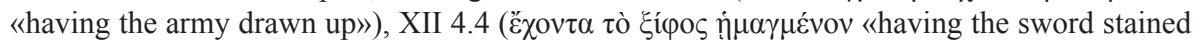

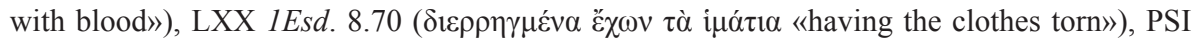

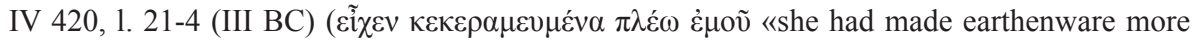

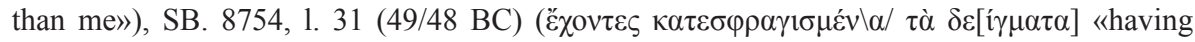
the (jars with) samples sealed up»).

${ }^{21}$ In fact, Bonfante 1960, p. 174, has suggested that the Latin construction of habeo with passive perfect participle should be considered a Graecism; «qu'est-ce que l'innovation

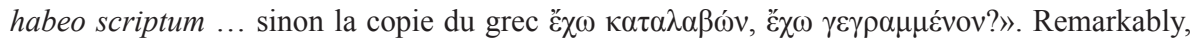
Bonfante lumps together two constructions ( $\varepsilon_{\chi} \chi \omega$ with active/middle aorist participle and $\varepsilon^{\prime} \chi \omega$ with passive perfect participle) which are diachronically unrelated and functionally dissimilar (the former functioning as an anterior perfect and the latter as a resultative perfect). The reason for this might be that the construction of $\ddot{\varepsilon} \chi \omega$ with passive perfect participle occurs too infrequently at an early stage to be of any direct influence on Latin.
} 
It seems more likely that Ancient Greek है $\chi \omega$ with passive perfect participle and Latin habeo with passive perfect participle constitute independent developments ${ }^{22}$, both originating from the (more common) pattern HAVE +

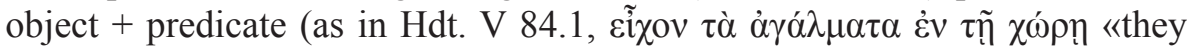
had the images in their country»; compare Pinkster 1987 for Latin). In both cases, the construction started out as a resultative perfect, from time to time allowing an anterior inference (which in Late Latin - but not in Ancient Greek-, through form-function reanalysis (Croft 2000, pp. 117-144), led to the formation of a true periphrastic anterior perfect). Of course, it cannot be entirely excluded that the existence of a HAVE-perfect (with passive perfect participle, that is) in one language has reinforced the use of a structurally similar construction in the other ${ }^{23}$.

As to the further development of the construction, consider Table 2, figuring the distribution of the construction per period and register (note that NRO does not include the papyri /low register).

This table shows that, as indicated by Horrocks, the construction catches on in MPG. However, we see that the construction is well attested in texts of the middle register (and to a lesser degree in the low register), and is hardly confined to the high-register work of authors such as Plutarch and Diodorus Siculus. Furthermore note that the construction continues to be used in LPG and EBG, though admittedly with a (small) decrease in frequency ${ }^{24}$.

${ }^{22}$ Cf. similarly Coleman 1975, p. 115. According to Coleman, however, (Post-Classical) $\varepsilon \chi \chi \omega$ with passive perfect participle should be considered an analogical extension of (Classical) $\varepsilon \chi \omega$ with active aorist participle, stimulated by the high frequency in Post-classical Greek of ciuí with passive perfect participle. Coleman's hypothesis is unsound: (a) since Ě $\chi \omega$ with active aorist participle has gone out of use already in Classical Greek (with the exception of the high register), I do not see how it could have motivated an analogical extension in PostClassical Greek; (b) the two constructions can hardly be considered functionally identical: $\tilde{\varepsilon} \chi \omega$ with active aorist participle is predominantly used as an anterior perfect, while $\tilde{\varepsilon} \chi \omega$ with passive perfect participle as a resultative perfect, so that one construction cannot simply have replaced the other, as Coleman suggests.

${ }^{23}$ For further discussion, see Bentein (forthc.).

${ }^{24}$ Contrast with Jannaris (1897, p. 498), according to whom by Byzantine times (i.e. from the seventh century onwards) and possibly even earlier (i.e. in LPG), the perfect, pluperfect

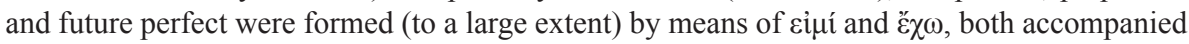
by a passive perfect participle, cỉ $\mu$ í serving for the passive voice (i.e. as an anterior perfect), and $\varepsilon^{\prime} \chi \omega$ for the active (i.e. as a resultative perfect). 
Table 2. Distribution of है $\chi \omega$ with passive perfect participle ${ }^{25}$

\begin{tabular}{|l|c|c|c|c|c|}
\hline \multicolumn{1}{|c|}{ Period } & Total & NRO & Low & Middle & High \\
\hline EPG & 38 & 0,3 & $2(5 \%)$ & $14(37 \%)$ & $22(58 \%)$ \\
\hline MPG & 64 & 0,7 & $9(14 \%)$ & $22(34 \%)$ & $33(52 \%)$ \\
\hline LPG & 69 & 0,6 & $6(9 \%)$ & $40(58 \%)$ & $23(33 \%)$ \\
\hline EBG & 33 & 0,5 & $2(6 \%)$ & $15(45 \%)$ & $16(49 \%)$ \\
\hline
\end{tabular}

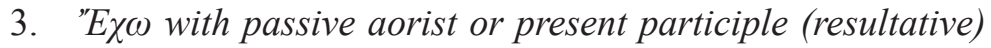

Quite surprisingly, the construction of है $\chi \omega$ with passive aorist or present participle has gone entirely unnoticed in the secondary literature. As an illustration, consider example (8), from the second-century Testament of Job, where $\varepsilon^{\prime} \chi \omega$ is combined with the passive aorist participle of the verb $\dot{\alpha} \lambda \lambda$ otó $\omega$ 'I change, alter'26.

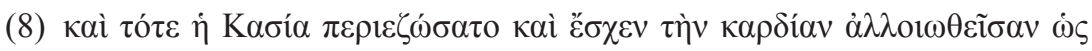

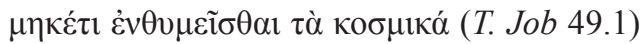

then the other daughter, Kassia by name, put on the girdle, and she had her heart transformed, so that she no longer wished for worldly things (tr. James, slightly modified)

The reason why mention is nowhere made of this construction is that during the entire period under investigation it has never transcended the (individual) level of innovation (in other words, it has never become con-

${ }^{25}$ Some caution is needed when interpreting the percentages given for the different registers, since the text samples chosen for each of them do not consist of an equal number of words. For the middle and high register, I have therefore also calculated NRO (occurrence per 10000 words): (1) EPG: Middle: 0,1; High: 0,7; (2) MPG: Middle: 0,8; High: 0,6; (3) LPG: Middle:0,7; High: 0,5; (4) EBG: Middle: 0,3; High: 1,1. This clarifies that in MPG the construction is relatively more frequently attested in the middle than in the high register (contrary to what the percentages would lead us to expect).

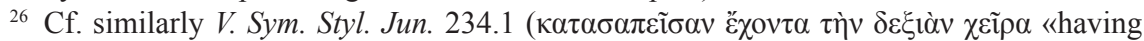

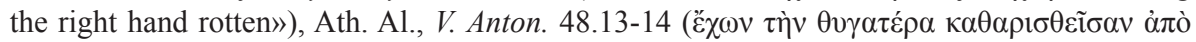

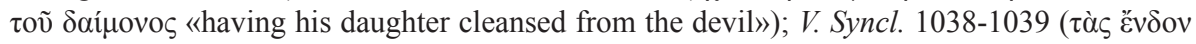

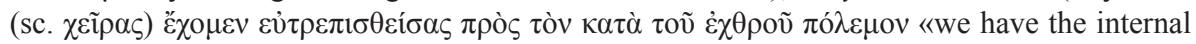
hands made ready for the war against the enemy»), Thdr. Stud., Laud. Theoph. Conf. 7.11

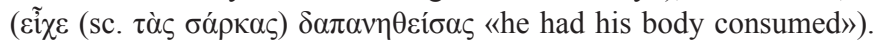


ventionalized — to a greater or lesser degree-). This innovation has come about through an analogical extension of the more common pattern $\varepsilon \chi \omega \omega+$ object + predicate (compare II.2), or more directly $\varepsilon^{\prime} \chi \omega+$ object + passive perfect participle (what Croft 2000, pp. 148-156 calls intraference). The intralingual identification of the perfect and aorist participle must have been stimulated by developments elsewhere in the verbal system, more in particular the functional merger of the synthetic perfect and aorist referred to in the introduction.

Even more uncommon is the construction of $\varepsilon^{\prime} \chi \omega$ with passive present participle, of which examples are only attested in LPG and EBG. In his discussion of periphrasis in John Malalas, Wolf (1912, p. 56) mentions our ex-

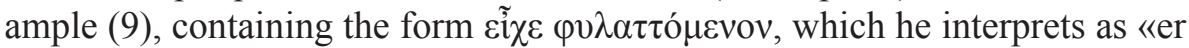
hielt verwahrt, habebat (tenebat) asservatum ${ }^{27}$. Again, we are dealing with a case of intraference, i.e. the extension of the passive perfect participle (accompanying $\left.\varepsilon^{\prime} \chi \omega\right)$ to the present participle.

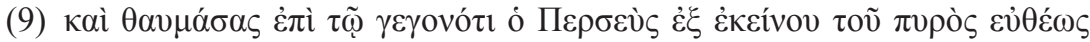

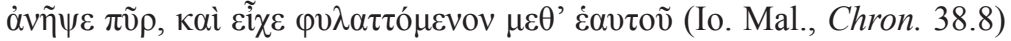
amazed by this event, Perseus immediately lit a fire from that fire and he kept it with him under protection (lit. guarded) (tr. Jeffreys et al.)

It may be interesting to note that the much more frequently attested resultative periphrastic perfect construction of cíui with perfect participle was extended in a similar way (i.e. first to cijú with passive aorist participle and at a later stage cíuí with passive present participle), as illustrated in (10) and (11):

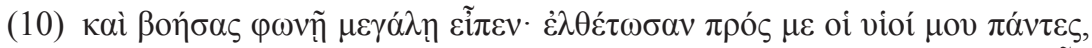

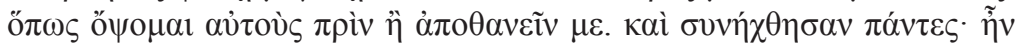

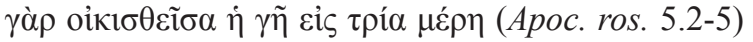

he cried with a loud voice and said: «Let all my sons come to me that I may see them before I die». And all assembled, for the earth was divided into three parts (tr. Charles)

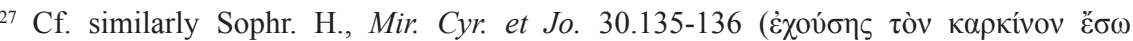

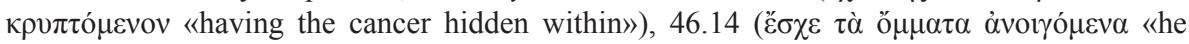

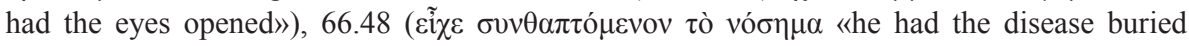
with him»). 


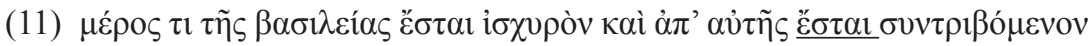
(LXX Dan. 2.42 - Thd. v.- - $)^{28}$

the kingdom shall be partly strong, and partly broken (KJV)

These resultative perfect constructions too have never become propagated, and as such have largely gone unnoticed in the secondary literature (Mirambel 1966, p. 183, does refer to eijui with passive aorist participle).

\section{4. 'E $\chi \omega$ with active/middle aorist or present participle and a temporal adjunct (anterior)}

The fourth and final construction which I would like to discuss here is $\varepsilon \chi \omega$ with active/middle aorist or present participle and a temporal adjunct, used with an anterior value. In illustration, consider example (12), where we find two examples of the construction in one and the same sentence (with two different types of participle):

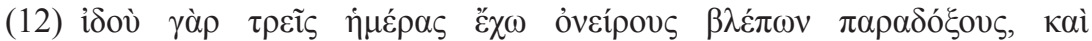

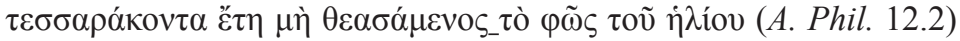

behold for I have been seeing incredible dreams for three days, and for forty years I have not seen the light of the sun (my translation)

In her recent book, Moser (2009, p. 219) compares examples of the kind found in (12) (the second instance, that is) with the Classical construction of है $\chi \omega$ with aorist participle (see II.1). This is incorrect in so far as we are dealing here with an entirely novel, Post-classical formation, which realizes a specific anterior sub-function and originates from a different source-construction altogether.

In the literature, the anterior sub-function realized by this construction is commonly called that of the «perfect of persistence» (see e.g. Comrie 1976, p. 60 ; Bentein 2012, p. 180). This type of perfect indicates that an event has begun in the past and is still ongoing at reference-time, as in «John has been coughing since Wednesday». While in Classical Greek this aspectual function never belonged to the semantic core-domain of the synthetic/periphrastic

28 The version by Theodotio is usually dated to the second century AD. Compare with the

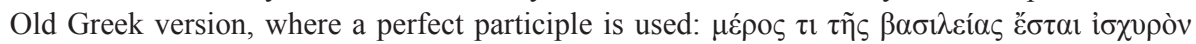

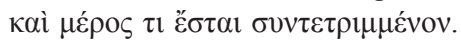


perfect $^{29}$, in Post-classical Greek a HAVE-perfect construction was propagated specifically for this purpose.

As indicated by (12), this construction could be formed either with a present or aorist participle. In this example, the most noteworthy difference of use between the two types of participle seems to lie in the fact that only the latter is accompanied by the negation $\mu$ í. Further analysis shows that this can be considered a structural feature: the negation occurs in 59\% (10/17) of the examples with the aorist participle ${ }^{30}$. I would argue that there is a semantic difference between examples with versus examples without the negation, favoring the use of the present versus the aorist participle: when the negation is used, we are dealing with a non-prototypical use of the perfect of persistence, as the event denoted by the participle in fact has not occurred during a certain time period including the present (or to be more precise the reference point). When the negation is not used, the continuation of the event denoted by the participle is stressed. The latter context seems to be much better suited to the present rather than the aorist participle ${ }^{31}$. As such, it is not surprising to find the aorist participle used in examples such as (13), which denote the persistence of an ongoing state, rather than event:

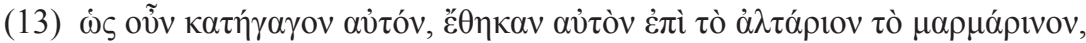

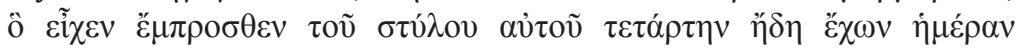
$\tau \varepsilon \lambda \varepsilon v \tau \eta ́ \sigma \alpha \varsigma$ (Anton. Hag., V. Sym. Styl. 29.21-23)

so when they brought him, they put him on the marble altar, which found itself before his pillar, having been dead for four days (my translation)

Previous scholarship (Tabachowitz 1943, p. 24; Aerts 1965, pp. 162-164; Porter 1989, pp. 490-491) has primarily focused on the fact that this con-

${ }^{29}$ As noted by Smyth (1984 [1920], pp. 422-424), Ancient Greek could simply use the present/imperfect tense to express this sub-function (though not exclusively, contra Haverling

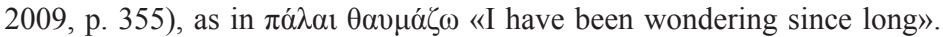

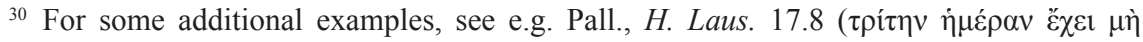

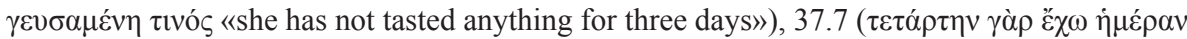

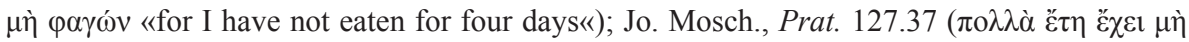
$\grave{\varepsilon} \xi \varepsilon \lambda \theta \omega \dot{v}$ «he has not gone out for many years»).

${ }^{31}$ Note, however, that this observation cannot be generalized. Consider e.g. Pall., H. Laus. 38.13 (

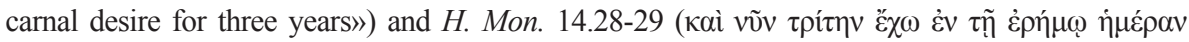

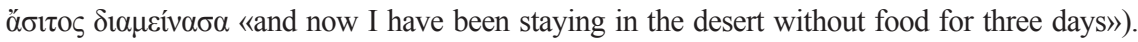


struction can be «reduced» to है $\chi \omega$ taking a (temporal) object (rather than an accusative of time) and the participle fulfilling an «explicative» function. In support of this claim, Aerts (1965, p. 164) mentions examples such as (14) and (15), which show that this explicative function could also be fulfilled by a temporal subclause or locative adjunct:

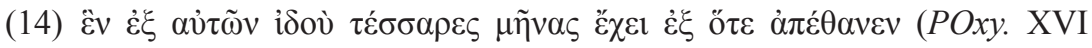
1862, 1. 17-8 [VII AD])

behold, one of them (the horses) died four months ago (lit. it has four months since it died) (my translation)

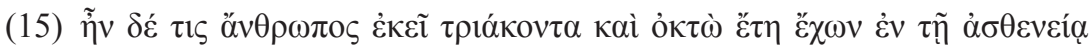

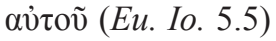

one man was there who had been ill for thirty-eight years (NRS)

Aerts (1965) and Porter (1989) both conclude that the construction in examples such as (12) cannot be considered «truly» periphrastic. From a diachronic point of view, however, this is of lesser importance: that the component parts of a construction are (syntactically/functionally) still comparatively «free» is typical for the early stages of grammaticalization (see Lehmann 1995 [1982] for the grammaticalization processes of rigidification and idiomaticization). What is most important is that we are dealing here with an innovative construction, which is not to be considered related to the earlier mentioned $\varepsilon \chi \omega$ with aorist participle (used in imitation of the Classical examples - see II.1-). This particular construction has come about through the mechanism of form-function reanalysis (Croft 2000, pp. 117-441), i.e. through the structural ambiguity inherent in the construction of है $\chi \omega$ accompanied by an accusative expressing time, next to a participle. Contrary to Aerts and others, I believe this ambiguity is also present in examples such as (15). As Liddell \& Scott (1968, pp. 749-750) indicate (see also Aerts 1965, p. 165), already in Classical times, है $\chi \omega$ is well attested with prepositional/ locative expressions (without a temporal object), where the verb is more or

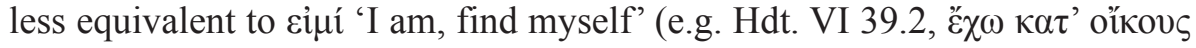

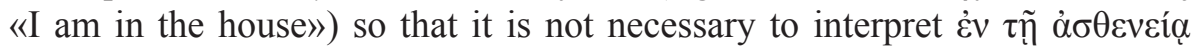

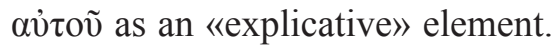

As for the diachronic development of the construction, consider the data represented in Table 3 (note again that NRO does not include the papyri /low register). 


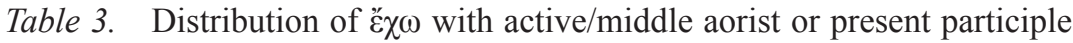
(anterior)

\begin{tabular}{|l|c|c|c|c|c|}
\hline \multicolumn{1}{|c|}{ Period } & Total & NRO & Low & Middle & High \\
\hline MPG & 3 & 0,04 & 0 & $3(100 \%)$ & 0 \\
\hline LPG & 29 & 0,3 & $2(7 \%)$ & $27(93 \%)$ & 0 \\
\hline EBG & 15 & 0,2 & 0 & $15(100 \%)$ & 0 \\
\hline
\end{tabular}

These data show that the construction first occurred in MPG (both with the present and aorist participle), at which stage it can still be considered an innovative construction ${ }^{32}$. In the following two periods, LPG and EBG, the construction «catches on», as indicated by an increase in frequency. Quite strikingly, the construction maintains a middle-register profile throughout these periods, though for LPG I have found two examples from the papyri, one of which is printed under (16):

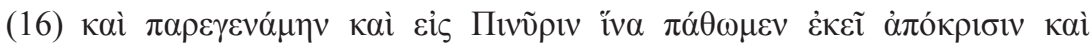

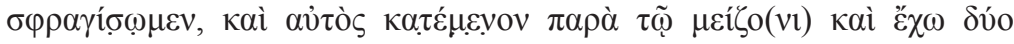

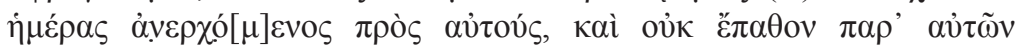
ảióкрıбıv (POxy. XVI 1855, 1. 8-10 [VI/VII AD])

I went also to Pinuris in order that I might get a response there and might affix the seal, and I remained myself with the headman and have been two days travelling up to them, and got no response from them (tr. Grenfell et al.)

\section{CONCLUDing REMARKS}

Scholars discussing the restructuring of the verbal system in Post-classical and Early Byzantine Greek generally stress the importance of periphrastic constructions with $\varepsilon i \mu$ í and $\varepsilon \chi \chi \omega$ replacing the synthetic perfect. In this article, I have shown that there are four main types of HAVE-perfect, whose development and use I have discussed in detail on the basis of an extensive

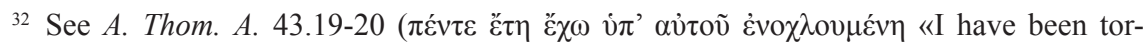

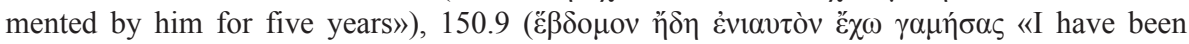

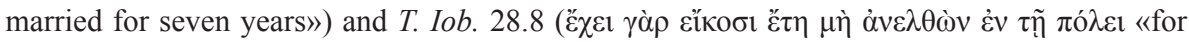
he has not entered the city for twenty years»). 
«register-balanced» corpus of texts. It may be clear that none of these four constructions had a major role to play in the period under analysis: the two anterior perfect constructions, $\varepsilon^{\prime} \chi \omega$ with active/middle aorist participle (II.1) and $\tilde{\varepsilon} \chi \omega$ with active/middle aorist or present participle and a temporal adjunct (II.4), were confined to the high and middle register respectively (with regard to the latter construction, we must also take into account that it was limited to an anterior sub-function which is contextually less often required). As for the two resultative constructions discussed here, "̌ $\chi \omega$ with passive perfect participle (II.2) and $\varepsilon \chi \omega \omega$ with passive aorist or present participle (II.3), the former construction did occur with some frequency (especially in MPG, arguably stimulated by the development of a similar construction in Latin), but never really took off. As noted above, the latter construction never transcended the (individual) level of innovation.

We should look upon these findings in close connection with the development of the synthetic tenses and other periphrastic constructions, especially those with the verb eíní (compare Nettle's notion of «ecological linkage» [Nettle 1999, p. 9]). In essence, the story of perfect periphrases in Post-classical and Early Byzantine Greek is that of 'be', not of 'have'. The functional specialization of eijui with (passive) perfect participle towards the resultative

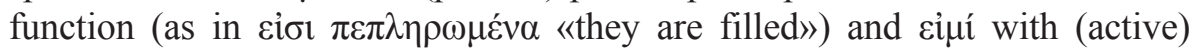
aorist participle towards the anterior function (as in $\tilde{\eta} \nu \lambda \alpha \beta \omega \dot{\omega} \nu$ «he had taken») left only very little room for the development of constructions with है $\chi \omega$ for either of the two main perfect functions (arguably with the exception of the «perfect of persistence» subfunction). ${ }^{33}$ With the breakdown of the participial system (affecting the active participle in particular), however, this situation again shifted quite dramatically in Middle and Late Byzantine Greek, as can still be seen by the presence of $\varepsilon^{\prime} \chi \omega$ periphrases (with the old aorist infinitive) in present-day Greek (on which, see e.g. Aerts 1965, pp. 168-183).

\section{REFERENCES}

Aerts, W. J. 1965: Periphrastica, Amsterdam, Hakkert (diss. Amsterdam).

Bentein, K. 2011: «On the construction of HAVE with passive perfect participle in Greek and Latin», Eranos: Acta Philologica Suecana 106, pp. 65-76.

\footnotetext{
${ }^{33}$ To given an idea, in the same corpus I have found nearly two thousand examples of these two BE-constructions.
} 
Bentein, K. 2012: «The periphrastic perfect in Ancient Greek. A diachronic mental space analysis», Transactions of the Philological Society 110, pp. 171-211.

Biber, D. and Conrad, S. 2009: Register, genre, and style, Cambridge, CUP.

Bonfante, G. 1960: «Les rapports linguistiques entre la Grèce et l'Italie», in Hommages à Léon Herrmann, Bruxelles, Latomus, pp. 171-183.

Browning, R. 1969: Medieval and modern Greek, Cambridge, CUP.

Bybee, J., Perkins, R. and Pagliuca, W. 1994: The evolution of grammar, Chicago, University of Chicago Press.

Cameron, A. 1991: Christianity and the rhetoric of empire, Berkeley, University of California Press.

Coleman, R. 1975: «Greek influence on Latin syntax», Transactions of the Philological Society 74, pp. 101-156.

Comrie, B. 1976: Aspect, Cambridge, CUP.

Cox, P. 1983: Biography in Late Antiquity, Berkeley, University of California Press.

Croft, W. 2000: Explaining language change: An evolutionary approach, Harlow, Longman.

Croft, W. 2006: «The relevance of an evolutionary model to historical linguistics», in Nedergård Thomsen, O. (ed.), Different models of linguistic change, Amsterdam, John Benjamins, pp. 91-132.

Dickey, E. 2003: «Latin influence on the Greek of documentary papyri: An analysis of its chronological distribution», Zeitschrift für Papyrologie und Epigraphik 145, pp. 249-257.

Dickey, E. 2009: «The Greek and Latin languages in the papyri», in: Bagnall, R. S. (ed.), Oxford handbook of papyrology, New York, Oxford University Press, pp. 149-169.

Fleischman, S. 2000: «Methodologies and ideologies in historical linguistics: On working with older languages», in Herring, S. C., van Reenen, P. and Schøsler, L. (eds.), Textual parameters in older languages, Amsterdam, Benjamins, pp. 33-58.

Gerö, E.-C. and von Stechow, A. 2003: «Tense in time: The Greek perfect», in Eckardt, R., von Heusinger, K. and Schwarze, C. (eds.), Words in time: Diachronic semantics from different points of view, Berlin, Mouton de Gruyter, pp. 251-294.

Giannaris, A. 2011a: «Pluperfect periphrases in Medieval Greek: A perspective on the collaboration between linguistics and philology», Transactions of the Philological Society 109, pp. 1-14.

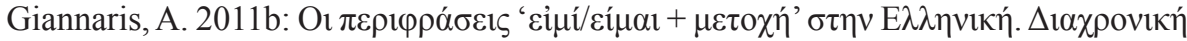
$\pi \rho \circ \sigma \varepsilon ́ \gamma \gamma ı \emptyset$, Ph.D. thesis, University of Athens.

Habermann, W. 1998: «Zur chronologischen Verteilung der papyrologischen Zeugnisse», Zeitschrift für Papyrologie und Epigraphik 122, pp. 144-160.

Haspelmath, M. 1992: «From resultative to perfect in Ancient Greek», in Iturrioz Leza, J. L. (ed.), Nuevos estudios sobre construcciones resultativas (= Función 
7/11-12), Universidad de Guadalajara, Centro de Investigación de Lenguas Indígenas, pp. 187-224.

Haverling, G. 2009: «Actionality, tense, and viewpoint», in Cuzzolin, P. and Baldi, P. (eds.), New perspectives on historical Latin syntax, Berlin-New York, Mouton de Gruyter, vol. 2, pp. 277-523.

Høgel, C. 2002: Symeon Metaphrastes, Copenhagen, Museum Tusculanum Press.

Horrocks, G. 2010: Greek: A history of the language and its speakers, OxfordMalden, Mass., Wiley-Blackwell.

Jannaris, A. 1897: An historical Greek grammar chiefly of the Attic dialect, Hildesheim, Olms.

Lampe, G. W. H. 1976: A patristic Greek lexicon, Oxford, Clarendon.

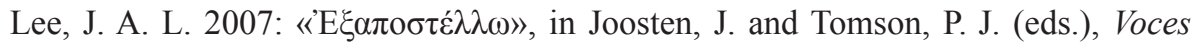
Biblicae: Septuagint Greek and its significance for the New Testament, Leuven, Peeters, pp. 99-113.

Lehmann, C. 1995 [1982]: Thoughts on grammaticalization, München, Lincom Europa.

Liddell, H. G. and Scott, R. 1968': A Greek-English lexicon, Oxford, Clarendon.

Mandilaras, B. G. 1972: Studies in the Greek language, Athens, N. Xenopoulos Press.

Manolessou, I. 2008: «On historical linguistics, linguistic variation and Medieval Greek», Byzantine and Modern Greek Studies 32, pp. 63-79.

Markopoulos, T. 2009: The future in Greek, Oxford, OUP.

Milroy, J. 1992: Linguistic variation and change, Oxford, Blackwell.

Mirambel, A. 1966: «Essai sur l'évolution du verbe en grec byzantin», Bulletin de la Société Linguistique de Paris 61, pp. 167-190.

Moser, A. 1988: A history of the perfect periphrases in Greek, Ph.D. Thesis, University of Cambridge.

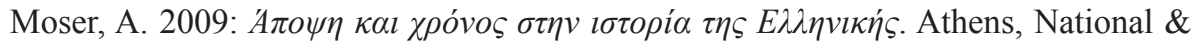
Kapodistrian University of Athens.

Mufwene, S. 2001: The ecology of language evolution, Cambridge, CUP.

Nettle, D. 1999: Linguistic diversity, Oxford, OUP.

O’Donnell, M. B. 2000: «Designing and compiling a register-balanced corpus of Hellenistic Greek for the purpose of linguistic description and investigation», in Porter, S. (ed.), Diglossia and other topics in New Testament linguistics, Sheffield, Sheffield Academic Press, pp. 255-297.

Pinkster, H. 1987. «The strategy and chronology of the development of future and perfect tense auxiliaries in Latin», in Harris, M. and Ramat, P. (eds.), Historical development of auxiliaries, Berlin, Mouton de Gruyter, pp. 193-223.

Porter, S. E. 1989: Verbal aspect in the Greek of the New Testament, New York, Peter Lang. 
Romaine, S. 1982: Socio-historical linguistics: Its status and methodology, Cambridge, CUP.

Ruijgh, C. 2004: «Over de gebruikswijzen van het Griekse perfectum. Met speciale aandacht voor Plato's Politeia», Lampas 37, pp. 24-45.

Salonius, A. H. 1927: Zur Sprache der griechischen Papyrusbriefe, Helsingfors, Akademische Buchhandlung.

Smyth, H. W. 1984 [1920]: Greek grammar, Harvard, Harvard University Press.

Tabachowitz, D. 1943: Études sur le grec de la basse époque, Uppsala, Almqvist \& Wiksell.

Thielmann, P. 1891: «"E $\chi \omega$ mit Particip», in Abhandlungen aus dem Gebiet der klassischen Altertums-Wissenschaft, München, Beck, pp. 294-306.

Traugott, E. and Dasher, R. 2002: Regularity in semantic change, Cambridge, CUP. Wolf, K. 1912: Studien zur Sprache des Malalas, München, Straub.

Fecha de recepción de la primera versión del artículo: 26/12/2011

Fecha de aceptación: 26/07/2012

Fecha de recepción de la versión definitiva: 30/07/2012 


\section{APPENDIX: PRIMARY (LITERARY) SOURCES}

Early Post-classical Greek (III - I BC)

\begin{tabular}{|l|l|l|l|}
\hline Septuagint & III/II BC & $\begin{array}{l}\text { A. Rahlfs. 1935. Septuaginta, 9th edn. } \\
\text { Stuttgart: Württemberg Bible Society. }\end{array}$ \\
\hline Histories & Polybius & III/II BC & $\begin{array}{l}\text { T. Büttner-Wobst. 1882-1904. Polybii } \\
\text { historiae. Leipzig: Teubner. }\end{array}$ \\
\hline $\begin{array}{l}\text { Apocalypse of } \\
\text { Enoch }\end{array}$ & II/I BC & $\begin{array}{l}\text { M. Black. 1970. Apocalypsis Henochi } \\
\text { Graece. Leiden: Brill. }\end{array}$ \\
\hline $\begin{array}{l}\text { Roman } \\
\text { Antiquities }\end{array}$ & $\begin{array}{l}\text { Dionysius of } \\
\text { Halicarnassus }\end{array}$ & I BC & $\begin{array}{l}\text { K. Jacoby. 1885-1905. Dionysii } \\
\text { Halicarnasei antiquitatum Romanarum } \\
\text { quae supersunt. Leipzig: Teubner. }\end{array}$ \\
\hline $\begin{array}{l}\text { Apocalypse of } \\
\text { Roses }\end{array}$ & & I BC/I AD & $\begin{array}{l}\text { C. Tischendorf. 1866. Apocalypses } \\
\text { apocryphae. Leipzig: Mendelssohn. }\end{array}$ \\
\hline
\end{tabular}

Middle Post-classical Greek (I - III AD)

\begin{tabular}{|l|l|l|l|}
\hline $\begin{array}{l}\text { Apocalypse of } \\
\text { Baruch }\end{array}$ & I AD & $\begin{array}{l}\text { J.C. Picard. 1967. Apocalypsis Baruchi } \\
\text { Graece. Leiden: Brill. }\end{array}$ \\
\hline New Testament & I AD & $\begin{array}{l}\text { K. Aland, M. Black, C.M. Martini, B.M. } \\
\text { Metzger \& A. Wikgren. 1968. The Greek } \\
\text { New Testament, 2nd edn. Stuttgart: } \\
\text { Württemberg Bible Society. }\end{array}$ \\
\hline $\begin{array}{l}\text { Testament of } \\
\text { Abraham }\end{array}$ & & I AD & $\begin{array}{l}\text { M.R. James. 1892. The testament of } \\
\text { Abraham. Cambridge: CUP. }\end{array}$ \\
\hline The Jewish war & $\begin{array}{l}\text { Flavius } \\
\text { Josephus }\end{array}$ & I AD & $\begin{array}{l}\text { B. Niese. 1895. Flavii Iosephi opera, } \\
\text { vol. 6. Berlin: Weidmann. }\end{array}$ \\
\hline Parallel lives ${ }^{35}$ & Plutarch & I/II AD & $\begin{array}{l}\text { K. Ziegler. 1964-71. Plutarchi vitae } \\
\text { parallelae, 2nd edn. Leipzig: Teubner. / } \\
\text { B. Perrin. 1914-26. Plutarch's lives. } \\
\text { Cambridge (Mass.): Harvard University } \\
\text { Press. }\end{array}$ \\
\hline Acts of Andrew & & II AD & $\begin{array}{l}\text { J.-M. Prieur. 1989. Acta Andreae. } \\
\text { Turnhout: Brepols. }\end{array}$ \\
\hline
\end{tabular}

${ }^{35}$ For Plutarch, I have concentrated on the lives of Agis and Cleomenes, Alexander, Antony, Caesar, Camillus, Cato the younger, Dion, Lucullus, Marius and Pompey 


\begin{tabular}{|c|c|c|c|}
\hline Acts of John & & II $\mathrm{AD}$ & $\begin{array}{l}\text { M. Bonnet. 1898. Acta apostolorum } \\
\text { apocrypha. Leipzig: Mendelssohn. }\end{array}$ \\
\hline Acts of Paul & & II $\mathrm{AD}$ & $\begin{array}{l}\text { C. Schmidt \& W. Schubart. 1936. Acta } \\
\text { Pauli. Glückstadt: Augustin. }\end{array}$ \\
\hline $\begin{array}{l}\text { Acts of Paul and } \\
\text { Thecla }\end{array}$ & & II $\mathrm{AD}$ & $\begin{array}{l}\text { R.A. Lipsius. 1891. Acta apostolorum } \\
\text { apocrypha. Leipzig: Mendelssohn. }\end{array}$ \\
\hline $\begin{array}{l}\text { Apocalypse of } \\
\text { John }\end{array}$ & & II AD & $\begin{array}{l}\text { C. Tischendorf. 1866. Apocalypses } \\
\text { apocryphae. Leipzig: Mendelssohn. }\end{array}$ \\
\hline $\begin{array}{l}\text { Acts of the } \\
\text { Scillitan } \\
\text { martyrs }\end{array}$ & & II $\mathrm{AD}$ & $\begin{array}{l}\text { J.A. Robinson. } 1891 \text {. The passion of } S \text {. } \\
\text { Perpetua. Cambridge: CUP. }\end{array}$ \\
\hline $\begin{array}{l}\text { Confession and } \\
\text { prayer of } \\
\text { Aseneth }\end{array}$ & & II $\mathrm{AD}$ & $\begin{array}{l}\text { M. Philonenko. 1968. Joseph et Aséneth. } \\
\text { Leiden: Brill. }\end{array}$ \\
\hline Gospel of Peter & & II $\mathrm{AD}$ & $\begin{array}{l}\text { M.G. Mara. 1973. Évangile de Pierre. } \\
\text { Paris: Éditions du Cerf. }\end{array}$ \\
\hline $\begin{array}{l}\text { Gospel of } \\
\text { Thomas }\end{array}$ & & II $\mathrm{AD}$ & $\begin{array}{l}\text { E. Klostermann. 1910. Apocrypha II. } \\
\text { Evangelien, 2nd edn. Bonn: Marcus \& } \\
\text { Weber. }\end{array}$ \\
\hline $\begin{array}{l}\text { Martyrdom of } \\
\text { Paul }\end{array}$ & & II $\mathrm{AD}$ & $\begin{array}{l}\text { R.A. Lipsius. 1891. Acta apostolorum } \\
\text { apocrypha. Leipzig: Mendelssohn. }\end{array}$ \\
\hline $\begin{array}{l}\text { Martyrdom of } \\
\text { Peter }\end{array}$ & & II $\mathrm{AD}$ & $\begin{array}{l}\text { L. Vouaux. 1922. Les actes de Pierre. } \\
\text { Paris: Letouzey \& Ané. }\end{array}$ \\
\hline $\begin{array}{l}\text { Proto- } \\
\text { evangelium of } \\
\text { James }\end{array}$ & & II $\mathrm{AD}$ & $\begin{array}{l}\text { É. de Strycker. 1961. La forme la plus } \\
\text { ancienne du protévangile de Jacque. } \\
\text { Brussels: Société des Bollandistes. }\end{array}$ \\
\hline $\begin{array}{l}\text { Testament of } \\
\text { Job }\end{array}$ & & II $\mathrm{AD}$ & $\begin{array}{l}\text { S.P. Brock. 1967. Testamentum Jobi. } \\
\text { Leiden: Brill. }\end{array}$ \\
\hline Acts of Justin & & II/III AD & $\begin{array}{l}\text { H. Musurillo. 1972. The acts of the } \\
\text { Christian martyrs. Oxford: Clarendon } \\
\text { Press. }\end{array}$ \\
\hline $\begin{array}{l}\text { Acts of the } \\
\text { Alexandrines }\end{array}$ & & II/III AD & $\begin{array}{l}\text { H. Musurillo. 1961. Acta } \\
\text { Alexandrinorum. Leipzig: Teubner. }\end{array}$ \\
\hline $\begin{array}{l}\text { Roman } \\
\text { Histories }\end{array}$ & Cassius Dio & II/III AD & $\begin{array}{l}\text { U.P. Boissevain. 1895-1901. Cassii } \\
\text { Dionis Cocceiani historiarum } \\
\text { Romanarum quae supersunt. Berlin: } \\
\text { Weidmann. }\end{array}$ \\
\hline
\end{tabular}


Late Post-classical Greek (IV - VI AD)

\begin{tabular}{|c|c|c|c|}
\hline Acts of Philip ${ }^{36}$ & & IV AD & $\begin{array}{l}\text { M. Bonnet. 1903. Acta apostolorum } \\
\text { apocrypha, vol. 2.2. Leipzig: } \\
\text { Mendelssohn. / F. Amsler, B. Bouvier \& } \\
\text { F. Bovon. 1999. Acta Philippi. Turnhout: } \\
\text { Brepols. }\end{array}$ \\
\hline $\begin{array}{l}\text { Collection of } \\
\text { ancient } \\
\text { martyrdoms }\end{array}$ & Eusebius & IV AD & $\begin{array}{l}\text { J.-P. Migne. 1857-1866. Patrologiae } \\
\text { cursus completus (series Graeca) }(M P G) \\
\text { 20. Paris: Migne. }\end{array}$ \\
\hline $\begin{array}{l}\text { Ecclesiastical } \\
\text { history }\end{array}$ & Eusebius & IV AD & $\begin{array}{l}\text { G. Bardy. 1952-8. Eusèbe de Césarée. } \\
\text { Histoire ecclésiastique. Paris: Éditions } \\
\text { du Cerf. }\end{array}$ \\
\hline $\begin{array}{l}\text { Encomium on } \\
\text { the holy forty } \\
\text { martyrs }\end{array}$ & $\begin{array}{l}\text { Ephraem the } \\
\text { Syrian }\end{array}$ & IV AD & 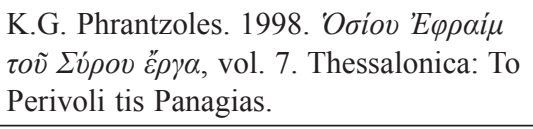 \\
\hline Lausiac history & Palladius & IV AD & $\begin{array}{l}\text { G.J.M. Bartelink. 1974. Palladio. La } \\
\text { storia Lausiaca. Verona: Fondazione } \\
\text { Lorenzo Valla. }\end{array}$ \\
\hline Life of Antony & Athanasius & IV AD & $\begin{array}{l}\text { G.J.M. Bartelink. 2004. Athanase } \\
\text { d'Alexandrie, Vie d'Antoine. Paris: } \\
\text { Éditions du Cerf. }\end{array}$ \\
\hline $\begin{array}{l}\text { Life of } \\
\text { Constantine }\end{array}$ & Eusebius & IV AD & $\begin{array}{l}\text { F. Winkelmann. 1975. Eusebius Werke, } \\
\text { Band 1.1: Über das Leben des Kaisers } \\
\text { Konstantin. Berlin: Akademie Verlag. }\end{array}$ \\
\hline $\begin{array}{l}\text { Life of St. } \\
\text { Macrina }\end{array}$ & $\begin{array}{l}\text { Gregory of } \\
\text { Nyssa }\end{array}$ & IV AD & $\begin{array}{l}\text { P. Maraval. 1971. Grégoire de Nysse. } \\
\text { Vie de sainte Macrine. Paris: Éditions du } \\
\text { Cerf. }\end{array}$ \\
\hline $\begin{array}{l}\text { Martyrium of } \\
\text { Pionius the } \\
\text { presbyter and } \\
\text { his comrades }\end{array}$ & & IV AD & $\begin{array}{l}\text { H. Musurillo. 1972. The acts of the } \\
\text { Christian martyrs. Oxford: Clarendon } \\
\text { Press. }\end{array}$ \\
\hline $\begin{array}{l}\text { On Gordius the } \\
\text { Martyr }\end{array}$ & $\begin{array}{l}\text { Basil of } \\
\text { Caesarea }\end{array}$ & IV AD & $\begin{array}{l}\text { J.-P. Migne. 1857-1866. Patrologiae } \\
\text { cursus completus (series Graeca) (MPG) } \\
\text { 31. Paris: Migne. }\end{array}$ \\
\hline
\end{tabular}

${ }^{36}$ I have taken into account the version based on the Xenophont. 32 and that based on the Vatic. gr. 824. 


\begin{tabular}{|c|c|c|c|}
\hline $\begin{array}{l}\text { On the life of } \\
\text { blessed } \\
\text { Abraham and } \\
\text { his } \\
\text { granddaughter } \\
\text { Maria }\end{array}$ & $\begin{array}{l}\text { Ephraem the } \\
\text { Syrian }\end{array}$ & IV AD & 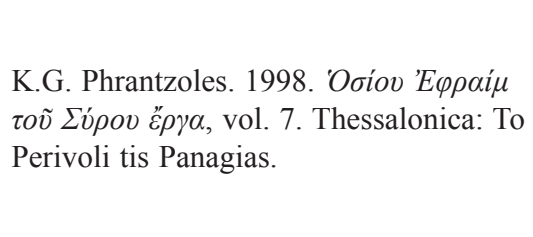 \\
\hline $\begin{array}{l}\text { On the life of } \\
\text { Gregory the } \\
\text { Wonderworker }\end{array}$ & $\begin{array}{l}\text { Gregory of } \\
\text { Nyssa }\end{array}$ & IV AD & $\begin{array}{l}\text { J.-P. Migne. 1857-1866. Patrologiae } \\
\text { cursus completus (series Graeca) (MPG) } \\
\text { 46. Paris: Migne. }\end{array}$ \\
\hline $\begin{array}{l}\text { On the life of } \\
\text { Moses }\end{array}$ & $\begin{array}{l}\text { Gregory of } \\
\text { Nyssa }\end{array}$ & IV AD & $\begin{array}{l}\text { J. Danielou. 1968. Grégoire de Nysse. } \\
\text { La vie de Moïse, 3rd edn. Paris: Éditions } \\
\text { du Cerf. }\end{array}$ \\
\hline $\begin{array}{l}\text { On the martyrs } \\
\text { of Palestine }\end{array}$ & Eusebius & IV AD & $\begin{array}{l}\text { G. Bardy. 1958. Eusèbe de Césarée. } \\
\text { Histoire ecclésiastique, vol. 3. Paris: } \\
\text { Éditions du Cerf. }\end{array}$ \\
\hline $\begin{array}{l}\text { Historical } \\
\text { fragments }\end{array}$ & Eunapius & IV/V AD & $\begin{array}{l}\text { L. Dindorf. 1870. Historici Graeci } \\
\text { minores, vol. 1. Leipzig: Teubner. }\end{array}$ \\
\hline $\begin{array}{l}\text { Ecclesiastical } \\
\text { history }\end{array}$ & $\begin{array}{l}\text { Theodoretus of } \\
\text { Cyrrhus }\end{array}$ & IV/V AD & $\begin{array}{l}\text { L. Parmentier \& F. Scheidweiler. } 1954 . \\
\text { Theodoret. Kirchengeschichte, 2nd edn. } \\
\text { Berlin: Akademie Verlag. }\end{array}$ \\
\hline $\begin{array}{l}\text { On those who } \\
\text { in Euphratesia } \\
\text { and the } \\
\text { Osrhoene } \\
\text { region, Syria, } \\
\text { Phoenicia and } \\
\text { Cilicia live the } \\
\text { monastic life }\end{array}$ & $\begin{array}{l}\text { Theodoretus of } \\
\text { Cyrrhus }\end{array}$ & IV/V AD & $\begin{array}{l}\text { J.-P. Migne. 1857-1866. Patrologiae } \\
\text { cursus completus (series Graeca) }(M P G) \\
\text { 83. Paris: Migne. }\end{array}$ \\
\hline $\begin{array}{l}\text { Acts of } \\
\text { Barnabas }\end{array}$ & & V AD & $\begin{array}{l}\text { M. Bonnet. 1903. Acta apostolorum } \\
\text { apocrypha, vol. 2.2. Leipzig: } \\
\text { Mendelssohn. }\end{array}$ \\
\hline $\begin{array}{l}\text { Ecclesiastical } \\
\text { history }\end{array}$ & Sozomenus & V AD & $\begin{array}{l}\text { J. Bidez \& G.C. Hansen. } 1960 . \\
\text { Sozomenus. Kirchengeschichte. Berlin: } \\
\text { Akademie Verlag. }\end{array}$ \\
\hline $\begin{array}{l}\text { Encomium on } \\
\text { John the Baptist }\end{array}$ & $\begin{array}{l}\text { Chrysippus of } \\
\text { Jerusalem }\end{array}$ & V AD & $\begin{array}{l}\text { A. Sigalas. 1937. Des Chrysippos von } \\
\text { Jerusalem Enkomion auf den hl. } \\
\text { Johannes den Täufer. Athens: Verlag der } \\
\text { Byzantinisch-neugriechischen } \\
\text { Jahrbücher. }\end{array}$ \\
\hline
\end{tabular}




\begin{tabular}{|c|c|c|c|}
\hline $\begin{array}{l}\text { Encomium on } \\
\text { St. Theodorus }\end{array}$ & $\begin{array}{l}\text { Chrysippus of } \\
\text { Jerusalem }\end{array}$ & $\mathrm{V} A D$ & $\begin{array}{l}\text { A. Sigalas. 1921. Des Chrysippos von } \\
\text { Jerusalem Enkomion auf den heiligen } \\
\text { Theodoros Teron. Leipzig: Teubner. }\end{array}$ \\
\hline $\begin{array}{l}\text { History of the } \\
\text { monks in Egypt }\end{array}$ & & $\mathrm{V} A D$ & $\begin{array}{l}\text { A.-J. Festugière. 1971. Historia } \\
\text { monachorum in Aegypto. Brussels: } \\
\text { Société des Bollandistes. }\end{array}$ \\
\hline $\begin{array}{l}\text { Laudation on } \\
\text { mother Mary }\end{array}$ & Proclus & $\mathrm{V} A D$ & $\begin{array}{l}\text { F.J. Leroy. 1967. L'homilétique de } \\
\text { Proclus de Constantinople. Vatican City: } \\
\text { Biblioteca Apostolica Vaticana. }\end{array}$ \\
\hline $\begin{array}{l}\text { Life of } \\
\text { Alexander }\end{array}$ & & $\mathrm{VAD}$ & $\begin{array}{l}\text { E. de Stoop. 1911. Vie d'Alexandre l' } \\
\text { Acémète. Turnhout: Brepols. }\end{array}$ \\
\hline $\begin{array}{l}\text { Life of } \\
\text { Pachomius }\end{array}$ & & $\mathrm{V} A D$ & $\begin{array}{l}\text { F. Halkin. 1982. Le corpus athénien de } \\
\text { saint Pachome. Genève: Cramer. }\end{array}$ \\
\hline $\begin{array}{l}\text { Life of } \\
\text { Porphyry } \\
\text { bishop of Gaza }\end{array}$ & $\begin{array}{l}\text { Mark the } \\
\text { Deacon }\end{array}$ & $\mathrm{VAD}$ & $\begin{array}{l}\text { H. Gregoire \& M.-A. Kugener. } 1930 . \\
\text { Marc le Diacre. Vie de Porphyre, évêque } \\
\text { de Gaza. Paris: Les Belles Lettres. }\end{array}$ \\
\hline $\begin{array}{l}\text { Life of St. } \\
\text { Hypatius }\end{array}$ & Callinicus & $\mathrm{V} A D$ & $\begin{array}{l}\text { G.J.M. Bartelink. 1971. Callinicos. Vie } \\
\text { d'Hypatios. Paris: Éditions du Cerf. }\end{array}$ \\
\hline $\begin{array}{l}\text { Life of St. } \\
\text { Syncletica }\end{array}$ & $\begin{array}{l}\text { Pseudo- } \\
\text { Athanasius }\end{array}$ & $\mathrm{VAD}$ & $\begin{array}{l}\text { L. Abelarga. 2002. The Life of Saint } \\
\text { Syncletica. Introduction - Critical Text - } \\
\text { Commentary. Thessalonica: Centre for } \\
\text { Byzantine Research. }\end{array}$ \\
\hline $\begin{array}{l}\text { Life of Symeon } \\
\text { Stylites the } \\
\text { Elder }\end{array}$ & $\begin{array}{l}\text { Antony the } \\
\text { Hagiographer }\end{array}$ & $\mathrm{V} A D$ & $\begin{array}{l}\text { H. Lietzmann. 1908. Das Leben des } \\
\text { heiligen Symeon Stylites. Leipzig: } \\
\text { Hinrichs. }\end{array}$ \\
\hline New History & Zosimus & $\mathrm{V} A D$ & $\begin{array}{l}\text { F. Paschoud. 1971-89. Zosime. Histoire } \\
\text { nouvelle, vols. 1-3.2. Paris: Les Belles } \\
\text { Lettres. }\end{array}$ \\
\hline $\begin{array}{l}\text { Passion of } \\
\text { Gregory the } \\
\text { Illuminator }\end{array}$ & Agathangelus & V AD & $\begin{array}{l}\text { G. Garitte. 1946. Documents pour l' } \\
\text { étude du livre d'Agathange. Rome: } \\
\text { Bibliotheca Apostolica Vaticana. }\end{array}$ \\
\hline Life of Isidorus & Damascius & V/VI AD & $\begin{array}{l}\text { C. Zintzen. 1967. Damascii vitae Isidori } \\
\text { reliquiae. Hildesheim: Olms. }\end{array}$ \\
\hline Chronography & John Malalas & VI AD & $\begin{array}{l}\text { L. Dindorf. 1831. Ioannis Malalae } \\
\text { chronographia. Bonn: Weber. }\end{array}$ \\
\hline
\end{tabular}




\begin{tabular}{|c|c|c|c|}
\hline $\begin{array}{l}\text { Laudation of } \\
\text { Theodorus } \\
\text { Graptus }\end{array}$ & $\begin{array}{l}\text { Theophanes of } \\
\text { Caesarea }\end{array}$ & VI AD & $\begin{array}{l}\text { J. Featherstone. } 1980 \text {. The praise } \\
\text { of Theodore Graptos by Theophanes } \\
\text { of Caesarea. Analecta Bollandiana } 98 \text {, } \\
104-50 .\end{array}$ \\
\hline $\begin{array}{l}\text { Life of } \\
\text { Abramius }\end{array}$ & $\begin{array}{l}\text { Cyril of } \\
\text { Scythopolis }\end{array}$ & VI AD & $\begin{array}{l}\text { E. Schwartz. 1939. Kyrillos von } \\
\text { Skythopolis. Leipzig: Hinrichs. }\end{array}$ \\
\hline Life of Cyriacus & $\begin{array}{l}\text { Cyril of } \\
\text { Scythopolis }\end{array}$ & VI AD & $\begin{array}{l}\text { E. Schwartz. 1939. Kyrillos von } \\
\text { Skythopolis. Leipzig: Hinrichs. }\end{array}$ \\
\hline $\begin{array}{l}\text { Life of } \\
\text { Euthymius }\end{array}$ & $\begin{array}{l}\text { Cyril of } \\
\text { Scythopolis }\end{array}$ & VI AD & $\begin{array}{l}\text { E. Schwartz. 1939. Kyrillos von } \\
\text { Skythopolis. Leipzig: Hinrichs. }\end{array}$ \\
\hline $\begin{array}{l}\text { Life of John the } \\
\text { Silentiary }\end{array}$ & $\begin{array}{l}\text { Cyril of } \\
\text { Scythopolis }\end{array}$ & VI AD & $\begin{array}{l}\text { E. Schwartz. 1939. Kyrillos von } \\
\text { Skythopolis. Leipzig: Hinrichs. }\end{array}$ \\
\hline Life of Sabas & $\begin{array}{l}\text { Cyril of } \\
\text { Scythopolis }\end{array}$ & VI AD & $\begin{array}{l}\text { E. Schwartz. 1939. Kyrillos von } \\
\text { Skythopolis. Leipzig: Hinrichs. }\end{array}$ \\
\hline $\begin{array}{l}\text { Life of Symeon } \\
\text { Stylites the } \\
\text { Younger }\end{array}$ & & VI AD & $\begin{array}{l}\text { P. van den Ven. 1962. La vie ancienne } \\
\text { de S. Syméon Stylite le jeune (521-592). } \\
\text { Bruxelles: Société des Bollandistes. }\end{array}$ \\
\hline $\begin{array}{l}\text { Life of } \\
\text { Theodosius }\end{array}$ & $\begin{array}{l}\text { Cyril of } \\
\text { Scythopolis }\end{array}$ & VI AD & $\begin{array}{l}\text { E. Schwartz. 1939. Kyrillos von } \\
\text { Skythopolis. Leipzig: Hinrichs. }\end{array}$ \\
\hline $\begin{array}{l}\text { Life of } \\
\text { Eutychius }\end{array}$ & $\begin{array}{l}\text { Eustratius the } \\
\text { Presbyter }\end{array}$ & VI/VII AD & $\begin{array}{l}\text { C. Laga. 1992. Eustratii presbyteri vita } \\
\text { Eutychii patriarchae } \\
\text { Constantinopolitani. Turnhout: Brepols. }\end{array}$ \\
\hline $\begin{array}{l}\text { Life of } \\
\text { Golinduch }\end{array}$ & $\begin{array}{l}\text { Eustratius the } \\
\text { Presbyter }\end{array}$ & VI/VII AD & 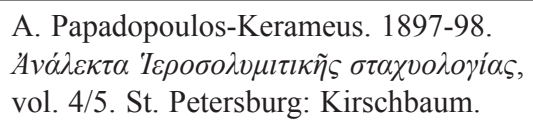 \\
\hline $\begin{array}{l}\text { Life of Martha } \\
\text { the mother of } \\
\text { Simeon Stylites } \\
\text { the Younger }\end{array}$ & & VI/VII AD & $\begin{array}{l}\text { P. van den Ven. 1970. La vie ancienne } \\
\text { de S. Syméon Stylite le jeune, vol. } 2 . \\
\text { Brussels: Société des Bollandistes. }\end{array}$ \\
\hline Life of Tycho & $\begin{array}{l}\text { John the } \\
\text { Merciful }\end{array}$ & VI/VII AD & $\begin{array}{l}\text { H. Usener. 1907. Sonderbare Heilige I. } \\
\text { Der heilige Tychon. Leipzig: Teubner. }\end{array}$ \\
\hline $\begin{array}{l}\text { Spiritual } \\
\text { Meadow }\end{array}$ & John Moschus & VI/VII AD & $\begin{array}{l}\text { J.-P. Migne. 1857-1866. Patrologiae } \\
\text { cursus completus (series Graeca) (MPG) } \\
\text { 87.3. Paris: Migne. }\end{array}$ \\
\hline
\end{tabular}




\section{Early Byzantine Greek (VII - VIII AD)}

\begin{tabular}{|c|c|c|c|}
\hline Apocalypse & $\begin{array}{l}\text { Pseudo- } \\
\text { Methodius }\end{array}$ & VII AD & $\begin{array}{l}\text { A.C. Lolos. 1976. Die Apokalypse des } \\
\text { Ps.-Methodios. Meisenheim am Glan: } \\
\text { Hain. }\end{array}$ \\
\hline Histories & $\begin{array}{l}\text { Theophylact } \\
\text { Simocatta }\end{array}$ & VII AD & $\begin{array}{l}\text { C. de Boor. 1887. Theophylacti } \\
\text { Simocattae historiae. Leipzig: Teubner. }\end{array}$ \\
\hline $\begin{array}{l}\text { Laudation of St. } \\
\text { Anastasius the } \\
\text { Persian }\end{array}$ & George Pisida & VII AD & $\begin{array}{l}\text { B. Flusin. 1992. Saint Anastase le Perse } \\
\text { et l'histoire de la Palestine au début du } \\
\text { viie siècle, vol. 1. Paris: Centre National } \\
\text { de la Recherche Scientifique. }\end{array}$ \\
\hline $\begin{array}{l}\text { Laudation of St. } \\
\text { John } \\
\text { Chrysostomus }\end{array}$ & $\begin{array}{l}\text { John of } \\
\text { Damascus }\end{array}$ & VII AD & $\begin{array}{l}\text { P.B. Kotter. 1988. Die Schriften des } \\
\text { Johannes von Damaskos, vol. 5. Berlin } \\
\text { \& New York: De Gruyter. }\end{array}$ \\
\hline $\begin{array}{l}\text { Laudation of St. } \\
\text { martyr } \\
\text { Anastasia }\end{array}$ & $\begin{array}{l}\text { John of } \\
\text { Damascus }\end{array}$ & VII AD & $\begin{array}{l}\text { P.B. Kotter. 1988. Die Schriften des } \\
\text { Johannes von Damaskos, vol. 5. Berlin } \\
\text { \& New York: De Gruyter. }\end{array}$ \\
\hline $\begin{array}{l}\text { Laudation of St. } \\
\text { martyr } \\
\text { Barabara }\end{array}$ & $\begin{array}{l}\text { John of } \\
\text { Damascus }\end{array}$ & VII AD & $\begin{array}{l}\text { P.B. Kotter. 1988. Die Schriften des } \\
\text { Johannes von Damaskos, vol. 5. Berlin } \\
\text { \& New York: De Gruyter. }\end{array}$ \\
\hline $\begin{array}{l}\text { Life of John the } \\
\text { Merciful }\end{array}$ & $\begin{array}{l}\text { Leontius of } \\
\text { Naples }\end{array}$ & VII AD & $\begin{array}{l}\text { A.-J. Festugière \& L. Rydén. } 1974 . \\
\text { Léontios de Néapolis, Vie de Syméon le } \\
\text { Fou et Vie de Jean de Chypre. Paris: } \\
\text { Geuthner. }\end{array}$ \\
\hline $\begin{array}{l}\text { Life of St. } \\
\text { Auxibius }\end{array}$ & & VII AD & $\begin{array}{l}\text { J. Noret. 1993. Hagiographica Cypria. } \\
\text { Turnhout: Brepols. }\end{array}$ \\
\hline $\begin{array}{l}\text { Life of St. } \\
\text { Gregory the } \\
\text { Theologian }\end{array}$ & $\begin{array}{l}\text { Gregory the } \\
\text { Presbyter }\end{array}$ & VII AD & $\begin{array}{l}\text { X. Lequeux. 2001. Gregorii Presbyteri } \\
\text { Vita Sancti Gregorii Theologi. Turnhout: } \\
\text { Brepols. }\end{array}$ \\
\hline $\begin{array}{l}\text { Life of St. } \\
\text { Symeon the } \\
\text { Fool }\end{array}$ & $\begin{array}{l}\text { Leontius of } \\
\text { Naples }\end{array}$ & VII AD & $\begin{array}{l}\text { A.-J. Festugière \& L. Rydén. } 1974 . \\
\text { Léontios de Néapolis, Vie de Syméon le } \\
\text { Fou et Vie de Jean de Chypre. Paris: } \\
\text { Geuthner. }\end{array}$ \\
\hline $\begin{array}{l}\text { Life of St. } \\
\text { Theodore of } \\
\text { Syceon }\end{array}$ & $\begin{array}{l}\text { George of } \\
\text { Syceon }\end{array}$ & VII AD & $\begin{array}{l}\text { A.-J. Festugière. 1970. Vie de Théodore } \\
\text { de Sykeôn, vol. 1. Brussels: Société des } \\
\text { Bollandistes. }\end{array}$ \\
\hline $\begin{array}{l}\text { xlv miracles of } \\
\text { St. Artemius }\end{array}$ & & VII AD & $\begin{array}{l}\text { A. Papadopoulos-Kerameus. 1909. Varia } \\
\text { graeca sacra. St. Petersburg: } \\
\text { Kirschbaum. }\end{array}$ \\
\hline
\end{tabular}




\begin{tabular}{|c|c|c|c|}
\hline $\begin{array}{l}\text { Miracles of } \\
\text { St. Demetrius }\end{array}$ & $\begin{array}{l}\text { John of } \\
\text { Thessalonica }\end{array}$ & VII AD & $\begin{array}{l}\text { P. Lemerle. 1979. Les plus anciens } \\
\text { recueils des miracles de saint Démétrius } \\
\text { et la pénétration des Slaves dans les } \\
\text { Balkans, vol. 1. Paris: Centre National } \\
\text { de la Recherche Scientifique. }\end{array}$ \\
\hline $\begin{array}{l}\text { Narration of the } \\
\text { miracles of Sts. } \\
\text { Cyrus and John }\end{array}$ & Sophronius & VII AD & $\begin{array}{l}\text { N. Fernández Marcos. 1975. Manuales y } \\
\text { anejos de Emérita 31, 243-400. Madrid: } \\
\text { Instituto Antonio de Nebrija. }\end{array}$ \\
\hline $\begin{array}{l}\text { Paschal } \\
\text { Chronicle }\end{array}$ & & VII AD & $\begin{array}{l}\text { L. Dindorf. 1832. Chronicon paschale, } \\
\text { vol. 1. Bonn: Weber. }\end{array}$ \\
\hline $\begin{array}{l}\text { Passion of the } \\
\text { great martyr } \\
\text { Artemius }\end{array}$ & $\begin{array}{l}\text { John of } \\
\text { Damascus }\end{array}$ & VII AD & $\begin{array}{l}\text { P.B. Kotter. 1988. Die Schriften des } \\
\text { Johannes von Damaskos, vol. 5. Berlin } \\
\text { \& New York: De Gruyter. }\end{array}$ \\
\hline $\begin{array}{l}\text { Two shorter } \\
\text { lives of } \\
\text { Theodore of } \\
\text { Syceon }\end{array}$ & & VII AD & $\begin{array}{l}\text { A.-J. Festugière. 1970. Vie de Théodore } \\
\text { de Sykeôn, vol. 1. Brussels: Société des } \\
\text { Bollandistes. }\end{array}$ \\
\hline $\begin{array}{l}\text { Passion of St. } \\
\text { Parasceva }\end{array}$ & John of Euboea & $\begin{array}{l}\text { VII/VIII } \\
\mathrm{AD}\end{array}$ & $\begin{array}{l}\text { F. Halkin. 1966. La Passion de Sainte } \\
\text { Parascève par Jean d'Eubée. } \\
\text { Heidelberg: Winter. }\end{array}$ \\
\hline $\begin{array}{l}\text { Life of St. } \\
\text { Benedictus }\end{array}$ & Pope Zacharias & VIII AD & $\begin{array}{l}\text { G. Rigotti. 2001. Vita di s. Benedetto } \\
\text { nella versione greca di papa Zaccaria. } \\
\text { Alessandria, Italy: Edizioni dell'Orso. }\end{array}$ \\
\hline $\begin{array}{l}\text { Martyrium of } \\
\text { Julian and } \\
\text { Basilissa }\end{array}$ & & VIII AD & $\begin{array}{l}\text { F. Halkin. 1980. La passion ancienne des } \\
\text { saints Julien et Basilisse. Analecta } \\
\text { Bollandiana 98, 243-96. }\end{array}$ \\
\hline Chronography & $\begin{array}{l}\text { Theophanes } \\
\text { Confessor }\end{array}$ & $\begin{array}{l}\mathrm{VIII} / \mathrm{IX} \\
\mathrm{AD}\end{array}$ & $\begin{array}{l}\text { C. de Boor. 1883. Theophanis } \\
\text { chronographia, vol. 1. Leipzig: Teubner. }\end{array}$ \\
\hline $\begin{array}{l}\text { Laudation of } \\
\text { John } \\
\text { Chrysostomus }\end{array}$ & $\begin{array}{l}\text { Cosmas } \\
\text { Vestitor }\end{array}$ & $\begin{array}{l}\mathrm{VIII} / \mathrm{IX} \\
\mathrm{AD}\end{array}$ & 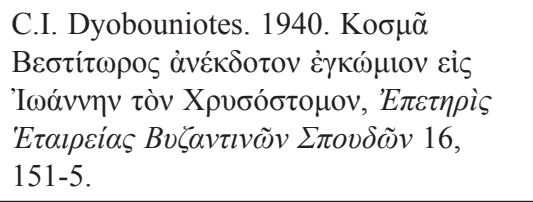 \\
\hline $\begin{array}{l}\text { Laudation of St. } \\
\text { Mocius }\end{array}$ & $\begin{array}{l}\text { Michael } \\
\text { Syncellus }\end{array}$ & $\begin{array}{l}\text { VIII/IX } \\
\mathrm{AD}\end{array}$ & $\begin{array}{l}\text { H. Delehaye. 1912. Saints de Thrace et } \\
\text { de Mésie. Analecta Bollandiana } 31 \text {, } \\
\text { 176-87. }\end{array}$ \\
\hline
\end{tabular}




\begin{tabular}{|c|c|c|c|}
\hline $\begin{array}{l}\text { Laudation of } \\
\text { Theophanes } \\
\text { Confessor }\end{array}$ & $\begin{array}{l}\text { Theodorus } \\
\text { Studites }\end{array}$ & $\begin{array}{l}\text { VIII/IX } \\
\text { AD }\end{array}$ & $\begin{array}{l}\text { S. Efthymiadis. 1993. Le panégyrique de } \\
\text { S. Théophane le Confesseur par S. } \\
\text { Théodore Stoudite (BHG 1792b). } \\
\text { Analecta Bollandiana 111, 268-84. }\end{array}$ \\
\hline $\begin{array}{l}\text { Life of Gregory } \\
\text { the Decapolite }\end{array}$ & $\begin{array}{l}\text { Ignatius the } \\
\text { Deacon }\end{array}$ & $\begin{array}{l}\text { VIII/IX } \\
\mathrm{AD}\end{array}$ & $\begin{array}{l}\text { G. Makris. 1997. Ignatios Diakonos und } \\
\text { die Vita des Hl. Gregorios Dekapolites. } \\
\text { Stuttgart: Teubner. }\end{array}$ \\
\hline $\begin{array}{l}\text { Life of } \\
\text { Nicephorus }\end{array}$ & $\begin{array}{l}\text { Ignatius the } \\
\text { Deacon }\end{array}$ & $\begin{array}{l}\text { VIII/IX } \\
\mathrm{AD}\end{array}$ & $\begin{array}{l}\text { C. de Boor. } 1880 . \text { Nicephori } \\
\text { archiepiscopi Constantinopolitani } \\
\text { opuscula historica. Leipzig: Teubner. }\end{array}$ \\
\hline $\begin{array}{l}\text { Life of St. } \\
\text { Andrew of Crete }\end{array}$ & $\begin{array}{l}\text { Nicetas the } \\
\text { Patrician }\end{array}$ & $\begin{array}{l}\text { VIII/IX } \\
\mathrm{AD}\end{array}$ & 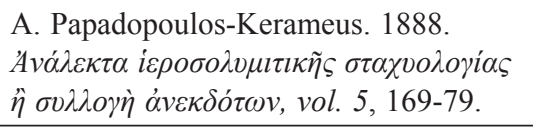 \\
\hline $\begin{array}{l}\text { Life of Stephan } \\
\text { the Younger }\end{array}$ & $\begin{array}{l}\text { Stephan the } \\
\text { Deacon }\end{array}$ & $\begin{array}{l}\text { VIII/IX } \\
\mathrm{AD}\end{array}$ & $\begin{array}{l}\text { M.-F. Auzépy. 1997. La Vie d'Étienne le } \\
\text { Jeune par Étienne le Diacre. Aldershot/ } \\
\text { Brookfield: Variorum. }\end{array}$ \\
\hline $\begin{array}{l}\text { Life of Tarasius } \\
\text { the Patriarch }\end{array}$ & $\begin{array}{l}\text { Ignatius the } \\
\text { Deacon }\end{array}$ & $\begin{array}{l}\text { VIII/IX } \\
\mathrm{AD}\end{array}$ & $\begin{array}{l}\text { S. Efthymiadis. 1998. The Life of the } \\
\text { Patriarch Tarasios by Ignatios the } \\
\text { Deacon. Aldershot, England: Ashgate. }\end{array}$ \\
\hline $\begin{array}{l}\text { Three } \\
\text { laudations on } \\
\text { St. Zacharias }\end{array}$ & $\begin{array}{l}\text { Cosmas } \\
\text { Vestitor }\end{array}$ & $\begin{array}{l}\text { VIII/IX } \\
\mathrm{AD}\end{array}$ & $\begin{array}{l}\text { F. Halkin. 1987. Zacharie, père de Jean } \\
\text { Baptiste. Trois panégyriques par Cosmas } \\
\text { Vestitor. Analecta Bollandiana } 105,252- \\
63 \text {. }\end{array}$ \\
\hline
\end{tabular}

